\title{
Apolipoprotein E-specific innate immune response in astrocytes from targeted replacement mice Izumi Maezawa $^{1}$, Nobuyo Maeda ${ }^{2}$, Thomas J Montine ${ }^{1}$ and Kathleen S Montine*1
}

\author{
Address: ${ }^{1}$ Department of Pathology, University of Washington, Seattle, WA, USA and 2Department of Pathology, University of North Carolina, \\ Chapel Hill, NC, USA \\ Email: Izumi Maezawa - imaezawa@u.washington.edu; Nobuyo Maeda - nobuyo@med.unc.edu; \\ Thomas J Montine - tmontine@u.washington.edu; Kathleen S Montine* - kmontine@u.washington.edu \\ ${ }^{*}$ Corresponding author
}

Published: 07 April 2006

Journal of Neuroinflammation 2006, 3:10 doi:10.1186/1742-2094-3-10

This article is available from: http://www.jneuroinflammation.com/content/3/1/10

(c) 2006 Maezawa et al; licensee BioMed Central Ltd.

This is an Open Access article distributed under the terms of the Creative Commons Attribution License (http://creativecommons.org/licenses/by/2.0), which permits unrestricted use, distribution, and reproduction in any medium, provided the original work is properly cited.
Received: 08 March 2006

Accepted: 07 April 2006

\begin{abstract}
Background: Inheritance of the three different alleles of the human apolipoprotein (apo) E gene $(A P O E)$ are associated with varying risk or clinical outcome from a variety of neurologic diseases. ApoE isoform-specific modulation of several pathogenic processes, in addition to amyloid $\beta$ metabolism in Alzheimer's disease, have been proposed: one of these is innate immune response by glia. Previously we have shown that primary microglia cultures from targeted replacement (TR) APOE mice have apoE isoform-dependent innate immune activation and paracrine damage to neurons that is greatest with TR by the $\varepsilon 4$ allele (TR APOE4) and that derives from $p 38$ mitogenactivated protein kinase (P38MAPK) activity.
\end{abstract}

Methods: Primary cultures of TR APOE2, TR APOE3 and TR APOE4 astrocytes were stimulated with lipopolysaccharide (LPS). ApoE secretion, cytokine production, and nuclear factor-kappa B (NF- $\mathrm{KB}$ ) subunit activity were measured and compared.

Results: Here we showed that activation of primary astrocytes from TR APOE mice with LPS led to TR APOE-dependent differences in cytokine secretion that were greatest in TR APOE2 and that were associated with differences in NF-kB subunit activity.

Conclusion: Our results suggest that LPS activation of innate immune response in TR APOE glia results in opposing outcomes from microglia and astrocytes as a result of TR APOE-dependent activation of P38MAPK or NF-KB signaling in these two cell types.

\section{Background}

Humans are different from other mammals in that we have 3 common alleles of the apolipoprotein $\mathrm{E}$ gene (APOE): the $\varepsilon 2$ (APOE2), $\varepsilon 3$ (APOE3), and 84 (APOE4) alleles [1]. Numerous genetic studies have associated inheritance of APOE4 with increased risk, earlier onset, or poorer clinical outcome for a number of neurodegenera- tive diseases, including Alzheimer's disease (AD), Parkinson's disease (PD), amyotrophic lateral sclerosis (ALS), traumatic brain injury, and HIV-encephalitis [2-10]. At least for $\mathrm{AD}$, inheritance of $A P O E 2$ is associated with apparent neuroprotection, perhaps related to delayed onset of illness by many years [11]. While apoE isoforms play a role in the metabolism of beta amyloid $(\mathrm{A} \beta)$ pep- 
tides and thereby may modulate the risk of developing $\mathrm{AD}$ [12], the influence of inheriting different APOE alleles extends well beyond diseases thought to involve $A \beta$ peptide-mediated neurotoxicity, as noted above. For this reason, other apoE-isoform specific mechanisms likely exist to explain the apparent influence of APOE alleles on such a broad spectrum of neurologic diseases; indeed, several have been proposed including synaptic stabilization, biologically active proteolytic fragments of apoE, anti-oxidant activity, and nitric oxide (NO) production [13-16]. ApoE also has an immune modulatory function, at least in the peripheral adaptive immune response to some bacteria and viruses [17]. We have recently shown that microglia from mice with targeted replacement (TR) of the mouse apoE gene with the coding sequences of human APOE alleles activated with LPS display an apoE isoformspecific innate immune response and result in apoE isoform-specific paracrine damage to neurons, both of which are dependent on p38 mitogen-activated protein kinase (p38MAPK) -mediated signaling.

One commonly used approach to investigate selectively innate immune response in neurodegeneration is to use a specific stimulus, lipopolysaccharide (LPS) [18-25]. LPS specifically activates CD14/Toll-like receptor (TLR) 4 coreceptors with subsequent increased gene transcription mediated through a bifurcated pathway that is dependent on both nuclear factor-kappa B (NF-кB) and p38MAPK signaling $[26,27]$. Indeed, LPS activation of CD14/TLR4 co-receptors on microglia leads to indirect damage to neurons and oligodendroglia in culture and in vivo $[22,28$ 30]. Moreover, a role for CD14/TLR4 co-receptors is now understood to extend well beyond endotoxemia, as they are important in innate immune response to several endogenous ligands [31]. Indeed, CD14 binds A $\beta$ fibrils and is responsible for most of $A \beta$-stimulated microglialmediated neurotoxicity [32]. In addition, peptides and neoantigens expressed by apoptotic cells also activate this pathway [33]. Here we tested the hypothesis that innate immune response from CD14/TLR4 activation would show isoform-specific differences in primary cultures of astrocytes from TR APOE mice.

\section{Methods \\ Materials}

Cell culture solutions and supplies were from GIBCO (Grand Island, NY). Poly-ornithine $(0.01 \%)$ was from Sigma (St. Louis, MO). 4-15\% SDS-polyacrylamide gels were from BioRad (Hercules, CA). LPS and the NO assay kit were from Calbiochem (La Jolla, CA). Primary antibodies used were polyclonal anti-human apoE antibody from Dako Corporation (Carpinteria, CA) and polyclonal anti-glial fibrillary astrocytic protein (GFAP) antibody from Novus Biologicals (Littleton, CO). The NF-kB tran- scription factor assay kit and purified human HDL were from Chemicon International (Temecula, CA)

\section{Mice}

Homozygous APOE2, APOE3 and APOE4 targeted replacement (TR) mice 'humanized' at apoE were developed by Dr. Maeda and colleagues [34,35]. Briefly, human $A P O E$ genomic fragments were used to replace mouse $a p o E$ via homologous recombination. All three lines of TR APOE mice contain chimeric genes consisting of mouse 5 ' regulatory sequences continuous with mouse exon 1 (noncoding) followed by human exons (and introns) 2-4 [34]. These mice were backcrossed greater than six generations to $\mathrm{C} 67 \mathrm{BL} / 6$ genetic background. Mice were housed in an ALAC-approved vivarium and methods approved by a University of Washington International Use and Care of Animals (IACUC) Committee.

\section{Astrocyte cultures}

Primary cultures of 1-day-old mouse cerebral cortical astrocytes were prepared according to the method of Gebicke-Haerter, et al. [36]. Confluent cultures were used on the $7^{\text {th }}$ day in vitro (DIV). Our preparations were $\geq 93 \%$ pure for astrocytes, as demonstrated by glial fibrillary acidic protein (GFAP) antibody. Astrocytes were exposed to LPS in serum-free medium at a final concentration of $100 \mathrm{ng} / \mathrm{ml}$ (20 ng/105 cells). Vehicle control for LPS exposure was PBS.

\section{Western blot analysis}

Conditioned (serum-free) medium was removed from astrocyte cultures following LPS or vehicle exposure and centrifuged at $13,000 \times \mathrm{g}$ for $2 \mathrm{~min}$ at $4{ }^{\circ} \mathrm{C}$ to remove cell debris. Equal volumes of conditioned media were diluted with 6X sample buffer (0.35 M Tris, 30\% glycerol, 10\% SDS, $0.93 \mathrm{~g}$ DTT, $1.2 \mathrm{mg}$ bromophenol blue), heated to $95^{\circ} \mathrm{C}$ for $5 \mathrm{~min}$, subjected to SDS PAGE, transferred to PVDF membranes, and analyzed and quantified as previously described [37]. Anti-human apoE (Dako) was used at 1:2000 dilution. Secondary antibody was HRP-conjugated anti-rabbit (1:3000).

\section{NO detection}

NO levels in conditioned media following incubation with LPS or vehicle were measured using a colorimetric NO assay kit (Calbiochem) where nitrate is first converted to nitrite by the NADH-dependent nitrate reductase, followed by nitrite measurement using the Griess Reagent.

\section{Cytokine measurements}

Conditioned medium following incubation with LPS or vehicle was screened for cytokines with an array method, and selected cytokines further quantified individually by sandwich ELISAs. The bead-based Liquichip ${ }^{\mathrm{TM}}$ Mouse 10Cytokine Kit (Qiagen Inc, Valencia CA) was used to simul- 


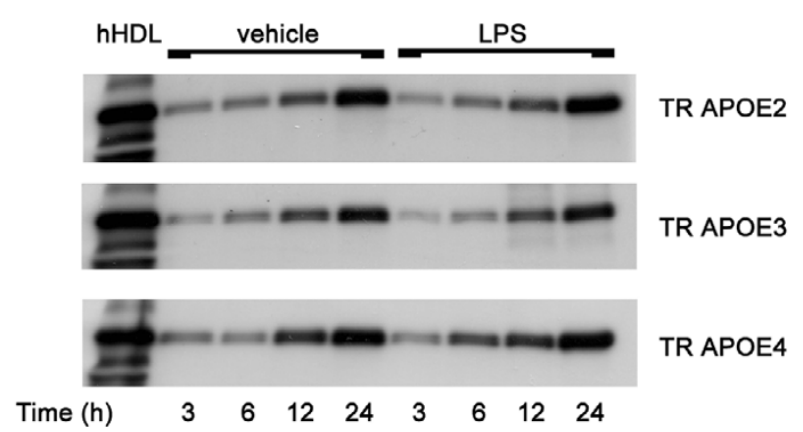

\section{Figure I}

ApoE secretion following LPS stimulation. Mouse cerebral primary astrocyte cultures were incubated in serumfree medium with $100 \mathrm{ng} / \mathrm{ml}$ LPS or vehicle (PBS) for 24 hours. $20 \mu$ l of conditioned medium was collected at $3,6,12$, and 24 hrs after exposure, spun briefly, mixed with $4 \mu \mathrm{l}$ of 6X sample buffer (0.35 M Tris, 30\% glycerol, I0\% SDS, $0.93 \mathrm{~g}$ DTT, and $1.2 \mathrm{mg}$ bromophenol blue), and relative concentrations of apoE determined by Western blotting. Human highdensity lipoprotein (hHDL) prepared in the same sample buffer was included as a positive control.

taneously screen conditioned media for the following cytokines: GM-CSF, interferon (INF)- $\gamma$, interleukin (IL)$1 \beta,-2,-4,-5,-6,-10,-12$, and tumor necrosis factor (TNF) $-\alpha$. This kit uses cytokine antibodies immobilized on LiquiChip $^{\mathrm{TM}}$ beads with distinct bead codes, which are added to conditioned media samples. Bead-bound cytokines are detected using a mixture of biotinylated cytokine-specific monoclonal antibodies and Streptavidin-PE. The specific bead code assigned to each of the 10 cytokines enables their unambiguous identification and quantification by a Luminex 100 X-Map reader using Qiagen software. Next, IL-6, IL-1 $\beta$, and TNF- $\alpha$ from conditioned media were separately quantified by sandwich ELISAs using DuoSet ELISA development kits for each cytokine (R\&D Systems, Minneapolis, MN).

\section{NF- $\kappa$ B activity}

$\mathrm{NF}-\kappa \mathrm{B}$ activity following incubation with LPS or vehicle was measured using an NF- $\kappa \mathrm{B}$ transcription factor assay kit from Chemicon International. Briefly, cells were rinsed with PBS, lysed in Buffer A (10 mM HEPES (pH7.9), 1.5 $\mathrm{mM} \mathrm{MgCl}_{2}, 10 \mathrm{mM} \mathrm{KCl}, 0.5 \mathrm{mM}$ DTT, 0.1\% Triton X-100 and protease inhibitor cocktail), and a nuclear extract prepared in Buffer B (20 mM HEPES ( $\mathrm{pH} 7.9), 1.5 \mathrm{mM}$ $\mathrm{MgCl}_{2}, 0.42 \mathrm{M} \mathrm{NaCl}, 0.2 \mathrm{mM}$ EDTA. $0.5 \mathrm{mM}$ DTT, $1.0 \%$ Igepal CA-630, 25\% (v/v) glycerol, and protease inhibitor cocktail). Double-stranded biotinylated oligonucleotide containing the flanked consensus sequence for NF- $\kappa$ B was mixed with the nuclear extract and the mixture immobi- lized on a streptavidin-coated chemiluminescent plate, followed by immunologic detection of the bound NF- $\kappa$ B transcription factor subunits p50 and 065 .

\section{Results}

We have recently reported that LPS activation of TR APOE glial-wt neuron mixed cultures for 24 hours results in apoE isoform-specific paracrine damage to neurons [30]. For activated microglia, TR APOE4 is more neurotoxic than TR APOE2 or APOE3. For activated astrocytes, which produce much less neurotoxicity than microglia, both TR APOE4 and TR APOE3 are mildly damaging to neurons, while TR APO2 shows no neurotoxic effect. In this previous work, we pursued apoE-isoform specific mechanisms in LPS-activated microglia and showed that these were p38MAPK-dependent. Here, we pursued the basis of apoE isoforms-specific differences in LPS activation of astrocytes from these TR mice.

We first showed that there was no difference among the three TR APOE astrocytes in the amount of secreted apoE following LPS exposure for up to 24 hours (Figure 1), in agreement with our findings for microglia [30]. We also determined that similar to microglia, there was no difference in medium nitrate plus nitrite levels (a measure of NO secretion) compared to wild type (wt) at 12 or 24 hours after LPS exposure $(\mathrm{P}>0.05)$, although we did observe increased medium nitrate plus nitrite levels in TR APOE4 (205 $\pm 41 \%$ of $w t)$ but not TR APOE2 (116 + 15\% of wt) astrocytes 72 hours after LPS incubation. As with microglia, this temporal mismatch suggests increased NO secretion by TR APOE4 lies distal to the processes underlying the TR-APOE isoform-specific differences in astrocyte-mediated neurotoxicity seen within 24 hours of LPS incubation [30].

Previously, we observed TR APOE-dependent differences in cytokine secretion by microglia in response to LPS exposure [30]. Here we measured cytokine secretion in response to LPS in the three TR APOE astrocyte cultures. We screened for changes in medium cytokine concentrations using the LiquiChip ${ }^{\mathrm{TM}}$ Mouse 10-Cytokine assay and a Luminex 100 X-Map reader that simultaneously determines 10 mouse cytokines in medium from TR APOE astrocytes. The cytokines quantified were GM-CSF, INF- $\gamma$, IL-1 $\beta$, IL-2, IL-4, IL-5, IL-6, IL-10, IL-12, and TNF- $\alpha$. Only IL- 6 and TNF- $\alpha$ changed significantly following LPS exposure for $12 \mathrm{hr}$; IL-1 $\beta$ was near the limit of detection for this assay. The magnitude of induction for these cytokines was TR APOE-dependent with IL- 6 and TNF- $\alpha$ concentrations following the gradient of TR APOE2 $>$ TR APOE3 $>$ TR APOE4. We confirmed our IL- 6 and TNF- $\alpha$ findings with individual ELISAs and extended our analysis to IL-1 $\beta$, since many others have shown it to be overexpressed and secreted from LPS-stimulated glia; TR APOE-dependence 

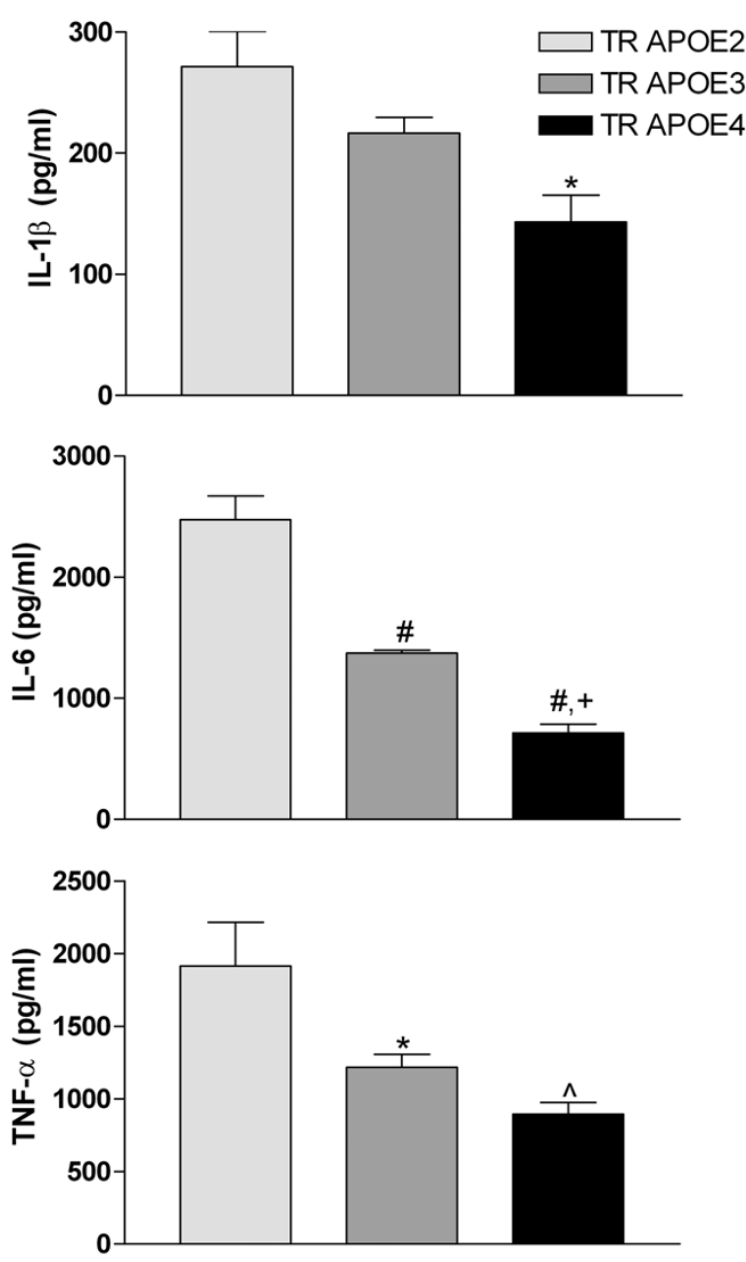

Figure 2

Cytokine secretion following LPS stimulation. Mouse cerebral primary astrocyte cultures were incubated in serum-free medium with $100 \mathrm{ng} / \mathrm{ml}$ LPS or PBS for $12 \mathrm{hr}$, medium collected, and IL-I $\beta$, IL- 6 and TNF- $\alpha$ concentrations determined by ELISA. All cytokines were below the limit of detection in PBS-exposed cultures. Data are mean \pm SEM ( $n$ $=4$ to 8 separate cultures per group). One-way ANOVA showed $\mathrm{P}<0.05$ for all three cytokines. $* \mathrm{P}<0.05$, ${ }^{\wedge} \mathrm{P}<0.0 \mathrm{I}$, or \#P $<0.001$ for Bonferroni-corrected posttests for LPSincubated TR APOE3 or TR APOE4 vs. TR APOE2; ${ }^{+P}<0.01$ for TR APOE4 vs. TR APOE3.

of IL-1 $\beta$ secretion followed the same pattern as the other two cytokines (Figure 2).

LPS activation of CD14/TLR4 co-receptors leads to subsequent increased gene transcription mediated through a bifurcated pathway that is dependent on NF- $\kappa \mathrm{B}$ and p38MAPK signaling. We have previously demonstrated apoE isoform-specific p38MAPK activation following LPS exposure of microglia but not astrocytes [30]. We therefore determined the activity of two NF- $\mathrm{kB}$ subunits, p50 and $\mathrm{p} 65$, in astrocytes from TR APOE mice (Figure 3). Following LPS exposure, both p50 and p65 activity significantly increased in all 3 genotypes. p50 activity showed an apoE isoform-specific increase, with a larger increase in TR APOE2 than the other two $(\mathrm{P}<0.01$ for both $)$ and no difference between TR APOE3 and TR APOE4. p65 showed a similar trend in apoE isoform-specific effect; however, this was not significantly different in corrected multiple comparison tests.

\section{Discussion}

Inheritance of $A P O E$ alleles is associated with varying clinical outcomes in several neurodegenerative diseases, including $\mathrm{AD}, \mathrm{PD}$, ALS, head trauma, multiple sclerosis, and HIV-encephalitis [2-10]. Although apoE isoforms likely modulate $\mathrm{AD}$ pathogenesis by influencing metabolism of $A \beta[12,38]$, the pathophysiologic significance of apoE isoforms appears to go beyond interacting with $A \beta$ since these other diseases of brain are not thought to involve $A \beta$ peptides in their pathogenesis. Indeed, others have suggested more general mechanisms of neurotrophism or neurotoxicity from inheritance of different APOE alleles that potentially could contribute to multiple neurologic diseases [13-16]. Since activation of innate immunity also is associated with these same diseases, we tested the hypothesis that apoE isoforms may act by modulating glial innate immune response and thereby altering neurotoxicity. Previously, we showed that microglia from TR APOE mice show apoE isoform-specific innate immune activation and paracrine damage to neurons that was greatest with TR APOE4 and dependent on p38MAPK signaling [30]. Here, we showed that identical activation of astrocytes from these same TR APOE mice had apoE isoforms-specific innate immune response that was greatest with TR APOE2 astrocytes and associated with NF-kBmediated signaling.

We used a model of selective activation of CD14/TLR4 coreceptors that is now appreciated to initiate innate immune response to endogenous ligands relevant to neurodegenerative diseases such as $A \beta$ fibrils as well as peptides and neoantigens expressed by apoptotic cells $[32,33]$. LPS activation of CD14/TLR4 co-receptors leads to increased gene transcription through a bifurcated pathway; one arm is NF-kB-dependent and the other is p38MAPK-dependent $[26,27]$. Our data indicated that the intracellular signaling that mediates altered gene transcription in response to LPS is different between astrocytes and microglia expressing TR APOE. Specifically, NF-кBmediated signaling, which is associated with immune modulation and protection of cells from undergoing apoptosis [39], was greatest in TR APOE2 astrocytes, the only cell line that did not yield paracrine damage to neurons following activation with LPS [30]. In contrast, apoE isoforms-specific effects in microglia, including much 

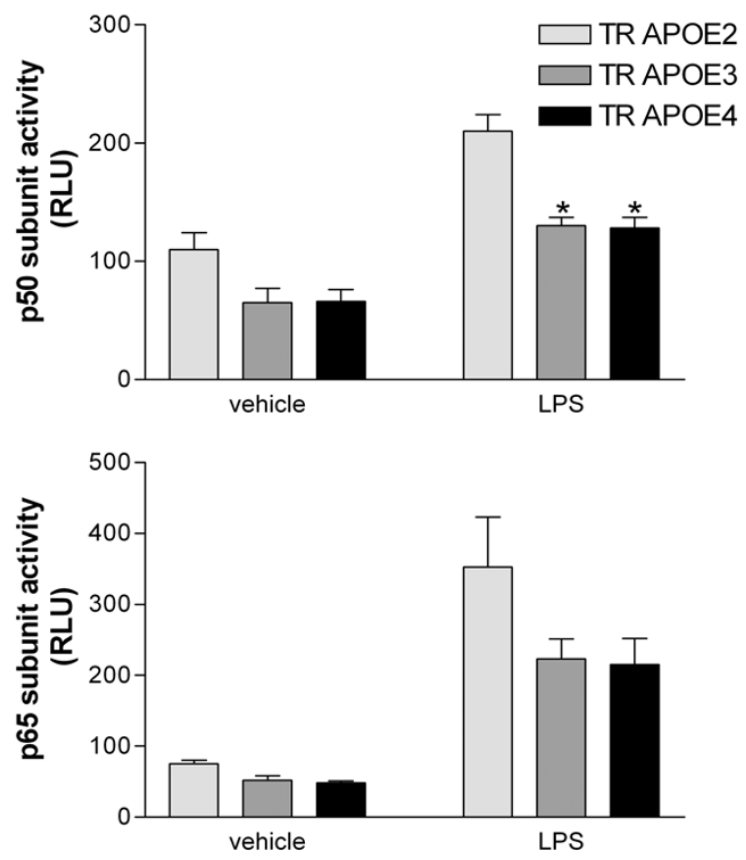

\section{Figure 3}

NF- $\kappa$ B activity following LPS stimulation. NF- $\kappa B$ p 50 and p65 subunit activity was determined in nuclear extracts from mouse cerebral primary astrocyte cultures exposed to vehicle (PBS) or LPS for $12 \mathrm{hr}$ using an NF- $\kappa B$ transcription factor assay kit (Chemicon). Data are expressed as average relative light units $(R L U) \pm S E M(n=4$ for each group). Twoway ANOVA for $\mathrm{P} 50$ data had $\mathrm{P}<0.000$ I for TR APOE and vehicle vs. LPS, but $P>0.05$ for interaction between these terms. Two-way ANOVA for $\mathrm{p} 60$ data had $P<0.05$ for TR APOE and $P<0.000$ I for vehicle vs. LPS, but $P>0.05$ for interaction between these terms. $* P<0.0$ I for Bonferronicorrected posttests for LPS-exposed TR APOE3 or TR APOE4 vs. TR APOE2.

more extensive paracrine damage to neurons, was associated with p38MAPK signaling [30]. We speculate that the inverse relationship between low-level neurotoxicity associated with LPS-activated astrocytes that we reported previously [30] and innate immune activation may be related to diminished NF- $\mathrm{B}$-dependent trophic factors in TR APOE3 and TR APOE4 astrocytes.

\section{Conclusion}

Our results suggest that LPS activation of innate immune response in TR APOE glia results in opposing outcomes from microglia and astrocytes as a result of TR APOEdependent activation of $\mathrm{p} 38 \mathrm{MAPK}$ or NF- $\kappa \mathrm{B}$ signaling in these two cell types.

\section{Abbreviations}

AD (Alzheimer's disease); ALS (amyotrophic lateral sclerosis); apo (apolipoprotein); APOE (human apoE gene); A $\beta$ (beta amyloid); DIV (days in vitro); GFAP (glial fibrillary astrocytic protein); hHDL (human high density lipoprotein); IL (interleukin); INF (interferon); LPS (lipopolysaccharide); NF- $\mathrm{B}$ (nuclear factor kappa B); NO (nitric oxide); p38MAPK (p38 mitogen-activated protein kinase); PD (Parkinson's disease); RLU (relative light units); TLR (Toll-like receptor); TNF (tumor necrosis factor); TR (targeted replacement); wt (wild type).

\section{Competing interests}

The author(s) declare that they have no competing interests.

\section{Authors' contributions}

IM carried out the experiments described. NM developed the mouse line that was used in all experiments. TJM conceived the study and its design and helped to draft the manuscript. KSM assisted in experimental design, analyzed the data, and drafted the manuscript.

\section{Acknowledgements}

This work was supported by the Nancy and Buster Alvord endowment and grants from the NIH (AG240II and AG05I36).

\section{References}

I. Mahley RW: Apolipoprotein E: cholesterol transport protein with expanding role in cell biology. Science 1988, 240(4852):622-630. Apr 29

2. Alberts MJ, Graffagnino C, McClenny C, DeLong D, Strittmatter WJ, Saunders AM, Roses AD: APOE genotype and survival from intracerebral hemorrhage. Lancet 1995, 346:575.

3. Newman MF, Croughwell ND, Blumenthal JA, Lowry E, White WD, Spillane W, Davis RD, Glower DD, Smith LR, Mahanna EP: Predictors of cognitive decline after cardiac operation. Ann Thorac Surg 1995, 59: 1326-1330.

4. Strittmatter WJ, Roses AD: Apolipoprotein E and Alzheimer disease. Proc Natl Acad Sci U S A 1995, 92:4725-4727.

5. Jordan BD, Relkin NR, Ravdin LD, Jacobs AR, Bennett A, Gandy S: Apolipoprotein $\mathrm{E}$ epsilon 4 associated with chronic traumatic brain injury in boxing. JAMA 1997, 278:| $36-140$.

6. Corder EH, Robertson K, Lannfelt L, Bogdanovic N, Eggertsen G, Wilkins J, Hall C: HIV-infected subjects with the E4 allele for APOE have excess dementia and peripheral neuropathy. Nat Med 1998, 4: II 82 - III 84.

7. Nathoo N, Chetty R, van Dellen JR, Barnett GH: Genetic vulnerability following traumatic brain injury: the role of apolipoprotein E. Mol Pathol 2003, 56:132-136.

8. Enzinger C, Ropele S, Smith S, Strasser-Fuchs S, Poltrum B, Schmidt $H$, Matthews PM, Fazekas F: Accelerated evolution of brain atrophy and "black holes" in MS patients with APOE-epsilon 4. Ann Neurol 2004, 55:563-569.

9. Li YJ, Hauser MA, Scott WK, Martin ER, Booze MW, Qin XJ, Walter JW, Nance MA, Hubble JP, Koller WC, Pahwa R, Stern MB, Hiner BC, Jankovic J, Goetz CG, Small GW, Mastaglia F, Haines JL, PericakVance MA, Vance JM: Apolipoprotein E controls the risk and age at onset of Parkinson disease. Neurology 2004, 62:2005-2009.

10. Li YJ, Pericak-Vance MA, Haines JL, Siddique N, McKenna-Yasek D, Hung WY, Sapp P, Allen Cl, Chen W, Hosler B, Saunders AM, Dellefave LM, Brown RHJ, Siddique T: Apolipoprotein $E$ is associated with age at onset of amyotrophic lateral sclerosis. Neurogenetics 2004, 5:209-2। 3 . 
II. Corder EH, Saunders AM, Risch NJ, Strittmatter WJ, Schmechel DE, Gaskell PCJ, Rimmler JB, Locke PA, Conneally PM, Schmader KE, al. : Protective effect of apolipoprotein $E$ type $\mathbf{2}$ allele for late onset Alzheimer disease. Nat Genet 1994, 7: 180-184.

12. Holtzman DM: In vivo effects of ApoE and clusterin on amyloid-beta metabolism and neuropathology. J Mol Neurosci 2004, 23:247-254.

13. Miyata M, Smith JD: Apolipoprotein E allele-specific antioxidant activity and effects on cytotoxicity by oxidative insults and beta-amyloid peptides. Nature Genetics 1996, I4:55-6I.

14. Brown CM, Wright E, Colton CA, Sullivan PM, Laskowitz DT, Vitek MP: Apolipoprotein $E$ isoform mediated regulation of nitric oxide release. Free Radic Biol Med 2002, 32: I07I-I 075.

15. Bock HH, Jossin Y, May P, Bergner O, Herz J: Apolipoprotein E receptors are required for reelin-induced proteasomal degradation of the neuronal adaptor protein Disabled-I. J Biol Chem 2004, 279:3347I-33479.

16. Brecht WJ, Harris FM, Chang S, Tesseur I, Yu GQ, Xu Q, Dee Fish J, Wyss-Coray T, Buttini M, Mucke L, Mahley RW, Huang Y: Neuronspecific apolipoprotein e4 proteolysis is associated with increased tau phosphorylation in brains of transgenic mice. J Neurosci 2004, 24:2527-2534.

17. Mahley RW, Rall SC]: Apolipoprotein E: far more than a lipid transport protein. Annu Rev Genomics Hum Genet 2000, I:507-537.

18. Stern EL, Quan N, Proescholdt MG, Herkenham M: Spatiotemporal induction patterns of cytokine and related immune signal molecule mRNAs in response to intrastriatal injection of lipopolysaccharide. J Neuroimmunol 2000, I 06: I |4- I29.

19. Hauss-Wegrzyniak B, Lynch MA, Vraniak PD, Wenk GL: Chronic brain inflammation results in cell loss in the entorhinal cortex and impaired LTP in perforant path-granule cell synapses. Exp Neurol 2002, I 76:336-34I.

20. Montine TJ, Milatovic D, Gupta RC, Valyi-Nagy T, Morrow JD, Breyer RM: Neuronal oxidative damage from activated innate immunity is EP2 receptor-dependent. J Neurochem 2002, 83:463-470.

21. Nadeau S, Rivest S: Endotoxemia prevents the cerebral inflammatory wave induced by intraparenchymal lipopolysaccharide injection: role of glucocorticoids and CDI4. J Immunol 2002, I 69:3370-338I.

22. Lehnardt S, Massillon L, Follett P, Jensen FE, Ratan R, Rosenberg PA, Volpe J], Vartanian T: Activation of innate immunity in the CNS triggers neurodegeneration through a Toll-like receptor 4dependent pathway. Proc Natl Acad Sci U S A 2003, 1 00:85 I4-85I 9.

23. Milatovic D, Zaja-Milatovic S, Montine KS, Horner PJ, Montine TJ: Pharmacologic suppression of neuronal oxidative damage and dendritic degeneration following direct activation of glial innate immunity in mouse cerebrum. J Neurochem 2003, 87:1518-1526.

24. Nadeau S, Rivest S: Glucocorticoids play a fundamental role in protecting the brain during innate immune response. J Neurosci 2003, 23:5536-5544.

25. Wenk GL, McGann-Gramling K, Hauss-Wegrzyniak B, Ronchetti D, Maucci R, Rosi S, Gasparini L, Ongini E: Attenuation of chronic neuroinflammation by a nitric oxide-releasing derivative of the antioxidant ferulic acid. I Neurochem 2004, 89:484-493.

26. Imler JL, Hoffmann JA: Toll receptors in innate immunity. Trends Cell Biol 200 I, I I:304-3 I I.

27. Akira S: Toll-like receptor signaling. J Biol Chem 2003, 278:38105-38108.

28. Milatovic D, Zaja-Milatovic S, Montine KS, Shie FS, Montine TJ: Neuronal oxidative damage and dendritic degeneration following activation of CDI4-dependent innate immune response in vivo. I Neuroinflammation 2004, I:20.

29. Shie FS, Montine KS, Breyer RM, Montine TJ: Microglial EP2 is critical to neurotoxicity from activated cerebral innate immunity. Glia 2005, 52:70-77.

30. Maezawa I, Nivison M, Montine KS, Maeda N, Montine TJ: Neurotoxicity from innate immune response is greatest with targeted replacement of E4 allele of apolipoprotein E gene and is mediated by microglial p38MAPK. Faseb J 2006, 20:797-799.

31. Johnson GB, Brunn GJ, Platt JL: Activation of mammalian Tolllike receptors by endogenous agonists. Crit Rev Immunol 2003, 23: I5-44.

32. Fassbender K, Walter S, Kuhl S, Landmann R, Ishii K, Bertsch T, Stal$\operatorname{der}$ AK, Muehlhauser F, Liu Y, Ulmer AJ, Rivest S, Lentschat A, Gul- bins $E$, Jucker M, Staufenbiel M, Brechtel K, Walter J, Multhaup G, Penke B, Adachi $Y$, Hartmann T, Beyreuther K: The LPS receptor (CDI4) links innate immunity with Alzheimer's disease. FASEB ] 2004, I 8:203-205.

33. Moffatt OD, Devitt A, Bell ED, Simmons DL, Gregory CD: Macrophage recognition of ICAM-3 on apoptotic leukocytes. J Immunol 1999, I 62:6800-68I0.

34. Sullivan PM, Mezdour H, Aratani Y, Knouff C, Najib J, Reddick RL, Quarfordt SH, Maeda N: Targeted replacement of the mouse apolipoprotein $E$ gene with the common human APOE3 allele enhances diet-induced hypercholesterolemia and atherosclerosis. J Biol Chem 1997, 272:I7972-I7980.

35. Sullivan PM, Mezdour H, Quarfordt SH, Maeda N: Type III hyperlipoproteinemia and spontaneous atherosclerosis in mice resulting from gene replacement of mouse Apoe with human Apoe*2. J Clin Invest 1998, 102:130-135.

36. Gebicke-Haerter PJ, Bauer J, Schobert A, Northoff H: Lipopolysaccharide-free conditions in primary astrocyte cultures allow growth and isolation of microglial cells. J Neurosci 1989, 9:183-194.

37. Maezawa I, Jin LW, Woltjer RL, Maeda N, Martin GM, Montine TJ, Montine KS: Apolipoprotein $\mathbf{E}$ isoforms and apolipoprotein $\mathbf{A I}$ protect from amyloid precursor protein carboxy terminal fragment-associated cytotoxicity. J Neuorchem 2004, 91:1312-1321.

38. Brendza RP, Bales KR, Paul SM, Holtzman DM: Role of apoE/Abeta interactions in Alzheimer's disease: insights from transgenic mouse models. Mol Psychiatry 2002, 7:132-135.

39. Clevers $\mathrm{H}$ : At the crossroads of inflammation and cancer. Cell 2004, I | 8:67|-674. 